\title{
Lithospheric model along transect HT-1 across Western Carpathians and Pannonian Basin based on 2D integrated modelling
}

\author{
Jana DÉREROVÁ ${ }^{1, *}$ (D) Miroslav BIELIK ${ }^{1,2}$ (D) , Igor KOHÚT ${ }^{1}$ (D), \\ Dominika GODOVÁ ${ }^{1,2}$ (D), Ján VOZÁR ${ }^{1}$ (D), Vladimír BEZÁK ${ }^{1}$ (D) \\ ${ }^{1}$ Division of Geophysics, Earth Science Institute of the Slovak Academy of Sciences \\ Dúbravská cesta 9, 84005 Bratislava, Slovak Republic \\ 2 Department of Applied and Environmental Geophysics, Faculty of Natural Sciences, \\ Comenius University, Mlynská dolina, Ilkovičova 6, 84215 Bratislava, Slovak Republic
}

\begin{abstract}
D integrated modelling approach was applied to determine the lithospheric structure along transect HT-1 located in the Carpathian-Pannonian Basin-European platform region. Our approach combines simultaneous interpretation of surface heat flow, topography, gravity and geoid data. All available geophysical and geological data were used to create an initial model that has been afterwards modified by trial and error method until reasonable fit was obtained between input data and model predictions. The main focus of our study was the position and shape of the lithosphere-asthenosphere boundary (LAB). In the Pannonian Basin the modelled LAB is at depths of about $80-90 \mathrm{~km}$ and rapidly dips towards the Western Carpathians where its depth reaches values 145 to $150 \mathrm{~km}$. Beneath the European platform the LAB depth is about $135-140 \mathrm{~km}$. We can observe a slight lithospheric root under the Western Carpathians. This lithospheric thickening is interpreted as a small remnant of a subducted slab. This result is in a good agreement with the previous lithospheric models in the Carpathian-Pannonian Basin.
\end{abstract}

Key words: integrated 2D modelling, heat flow, topography, gravity, geoid, lithosphere, asthenosphere, Carpathian-Pannonian-European platform

\section{Introduction}

The Carpathian-Pannonian-European platform area with its geological complexity provides a great opportunity to study the structure of the lithosphere, the asthenospheric and lithospheric processes taking place within it and their mutual interaction during the continental collision, the orogeny,

\footnotetext{
*corresponding author: e-mail: geofjade@savba.sk
} 
the volcanic arc and related fore-arc and back-arc basin development. For the study of the lithospheric structure we utilize the 2D integrated modelling method that simultaneously interprets different geophysical data. This method has already been used to estimate the lithospheric structure along several transects passing through the Western and Eastern Carpathians and the Pannonian Basin (Zeyen et al., 2002; Dérerová et al., 2006; Hlavñová et al., 2015). In this paper we present a lithospheric structure model along the Carpathian-Pannonian-European platform transect HT-1 that passes through the High Tatras mountains.

Transect HT-1 (Fig. 1) starts in the Drava depression in Croatia, then goes along the eastern margin of the Zala Basin and continues northeast through the Trans-Danubian central range. After leaving this area, the profile enters the easternmost part of the Danube Basin, continues through the Central Slovakia Volcanic Field, the Internal Western Carpathians, the High Tatras, the Pieniny Klippen belt, the External Western Carpathians, the Carpathian Foredeep, the Trans-European Suture Zone (Malopolska Block) and ends in the European Platform. The length of the transect is approximately $760 \mathrm{~km}$.

\section{Geological settings}

The Drava depression is a part of the southwestern part of the Pannonian Basin system, which had been formed as a back-arc system due to lithospheric extension and mantle upwelling behind the Carpathian arc (e.g. Csontos et al., 1992; Horváth, 1993; Kováč, 2000). The Drava depression is filled with Tertiary and Quaternary strata. The thickness of the sedimentary filling varies between 0 and $6 \mathrm{~km}$ (Bielik, 1988; Kilényi and Šefara, 1989; Bielik et al., 2005).

The Transdanubian Range (Haas et al., 2001) consists of the Palaeozoic, Triassic and Mesozoic formations. In some parts the Carboniferous granite forms part of the crystalline basement of this tectonic unit. Its northeastern part is made up of Eocene andesite.

The Central Slovakia Volcanic Field is an extensive volcanic region of the Carpathian arc and the Pannonian Basin. Its origin is related to processes of subduction and back-arc extension during Neogene evolution of the arc (Vozár et al., 1999). 


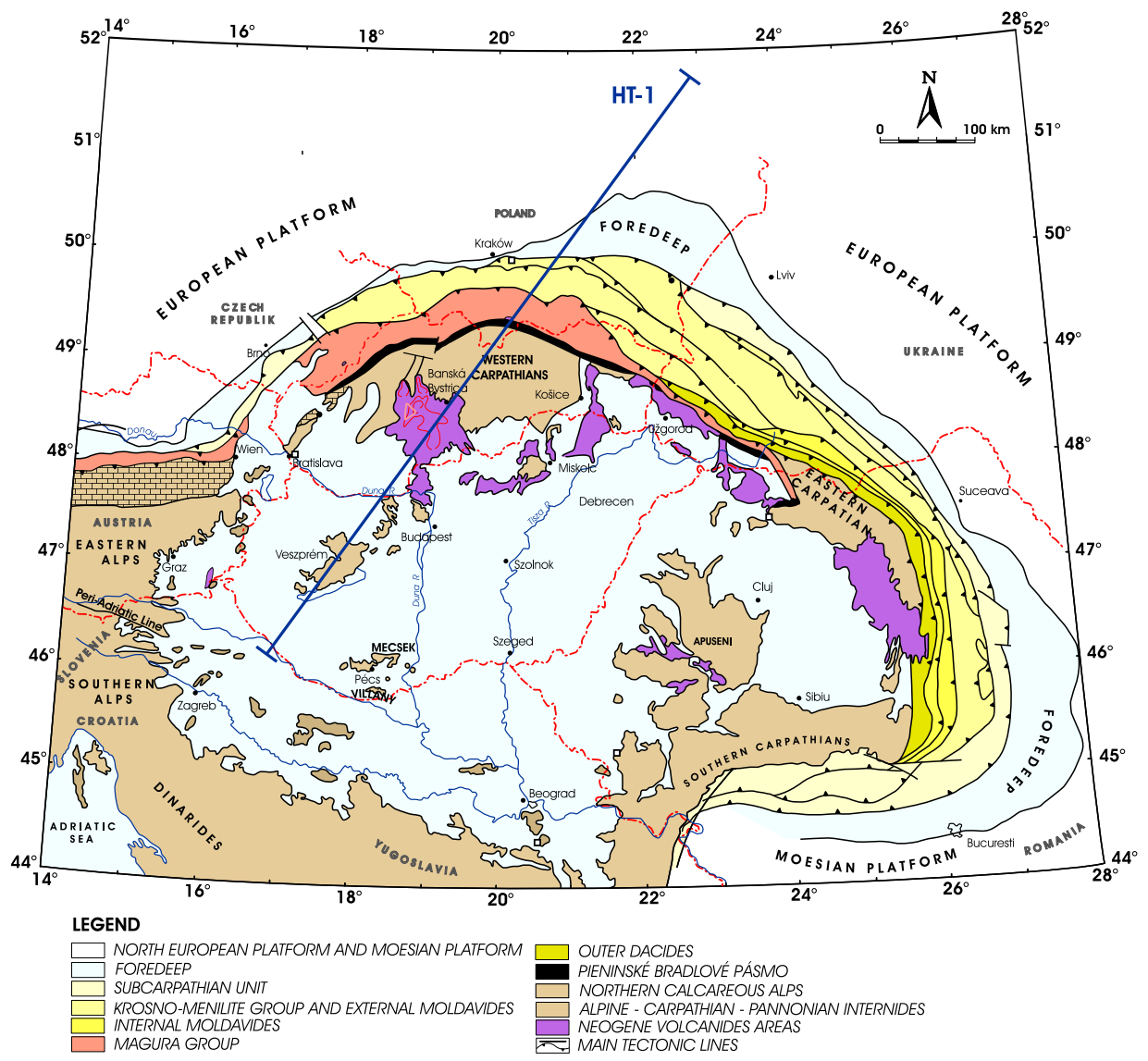

Fig. 1. Location of profile HT-1 on the map of the Carpathian-Pannonian-European platform region.

The Western Carpathians result from a series of Jurassic to Tertiary subduction and collision events during the Alpine orogeny (McCann, 2008a, 2008b). Tectonically, the Western Carpathians have a complicated geological structure formed since the Paleozoic era. The oldest Paleozoic rocks experienced the first stage of deformation during the Hercynian orogeny, but younger Alpine overprint is common. Alpine orogeny affected the area in several stages from Jurassic to Neogene. During this period, parts of the Tethys Ocean were subducted under the African plate, while the Western Carpathian blocks (microplate ALCAPA) were thrust over the margin of 
the Eurasian plate. They are divided into the External and Internal Western Carpathians. The boundary between them is formed by the Pieniny Klippen Belt (PKB). The PKB is a highly compressed narrow zone with layers of Jurassic to Lower Cretaceous limestone "klippen" surrounded by more plastic Cretaceous marl (Hók et al., 2014; Plašienka et al., 2020). The Internal Western Carpathians were subject to extensive crustal shortening (Plašienka et al., 1997) and include various pre-Tertiary units. The External Western Carpathians include the Carpathian Flysch Belt composed of several north-west, north, and north-east verging nappes, and the Carpathian Foredeep filled by Neogene strata.

The East-European Platform (EEP) formed during Precambrian. It is composed of Proterozoic igneous and metamorphic rocks covered by Vendian and Palaeozoic strata (Dadlez et al., 2005). It is separated from the younger Paleozoic Platform to the SW by the Trans-European Suture Zone (TESZ, e.g. Pharaoh, 1999). The zone is a broad (up to $200 \mathrm{~km}$ ) zone, crossing Europe from the North Sea to the Black Sea.

\section{Method}

2D integrated modelling method is an approach that combines joint interpretation of several geophysical fields, namely gravity anomalies, topographic heights, geoidal heights and surface heat flow data. A detailed description of the method can be found in (Zeyen and Fernàndez, 1994; Zeyen et al., 2005). A 2D finite element algorithm calculates the two-dimensional temperature distribution in the lithosphere, given its thickness, defined as the $1300^{\circ} \mathrm{C}$ isotherm, and the distribution of heat production and thermal conductivity solving the steady state heat conduction equation:

$\lambda \nabla^{2} T=A$,

where $\lambda$ is the thermal conductivity $\left(\mathrm{Wm}^{-1} \mathrm{~K}^{-1}\right), T$ the temperature $\left({ }^{\circ} \mathrm{C}\right)$ and $A$ the heat production $\left(\mathrm{Wm}^{-3}\right)$.

Based on temperatures that are calculated at every node, densities are determined at the same nodes, depending on temperature and pressure, as well as on predefined densities at room conditions. In the upper crust, with relatively low temperatures and high porosities, pressure and temperature effects are supposed to balance each other. In the lower crust and 
lithospheric mantle, the density decrease due to temperature is usually supposed to be stronger than the increase due to pressure except for very low temperature gradients. In our calculations, we assumed a thermal expansion coefficient of $3 \times 10^{-5} \mathrm{~K}^{-1}$. The obtained density distribution serves for calculation of the gravity (Bouguer or free air) anomalies along the transects (Talwani et al., 1959) and, for every column of the model, the topography under the assumption of local isostatic equilibrium based on the formulas given by Lachenbruch and Morgan (1990). The formulas used to calculate geoid have been published by Zeyen et al. (2005).

The joint use of gravity, topography and geoid data enables us to distinguish between density variations at different depths. Shallow (crustal) density variations are better controlled by the gravity data, especially if the crustal structure is known. Density variations in the deeper lithosphere are supposed to be mainly due to temperature variations and have a strong influence on long wavelength component of topographic heights, but relatively little effect on gravity. The geoid, reflecting variations in the undulation of the equipotential surface of the actual potential at sea level, above the equipotential surface of the normal potential (the normal reference ellipsoid) vanishes with inverse distance. Therefore, the geoid, compared to gravity anomalies, which vanish with the inverse square distance, is more sensitive to density variations in the lower lithosphere than in the crust. In addition, to suppress the effect of sub-lithospheric density variations on the geoid, the long-wavelength component of the geoid in terms of spherical harmonics up to degree and order 8 was removed (cf., Bowin, 1991; Zeyen et al., 2005).

\section{Geophysical data and starting model}

\subsection{Input geophysical data}

The surface heat flow data were compiled from the worldwide data set of Pollack et al. (1993). Topography data were taken from the GTOPO30 database (Gesch et al., 1999). The free air gravity anomalies were taken from the TOPEX 1-min gravity data set (ftp://topex.ucsd.edu/pub (Sandwell and Smith, 1997)). Geoid data were taken from the EGM-2008 global model (Pavlis et al., 2008). 
Mantle heterogeneities produce long-wavelength, high-amplitude anomalies that dominate the geoid. Consequently the observed geoid anomaly is the combination of mass anomalies in both the lithosphere and the sublithospheric mantle. In order to use the geoid for the study of the distribution of masses in the lithosphere, we remove the spectral part of the geoid assumed to be generated by the lower mantle, by means of removing the low degree and order spherical harmonics Bowin (1991) and Chase et al. (2002) advocate the removal of harmonics up to degrees 7 or 11. For the lithosphere of the Carpathian-Pannonian-European platform region with estimated thickness varying in the range $80-220 \mathrm{~km}$, the removal of spherical harmonics up to degree and order 8 is recommended (Zeyen et al., 2005; Dérerová et al., 2006).

For each geophysical dataset, we have extracted several parallel profiles to calculate the lateral variability of the data.

\subsection{Creation of starting model}

The starting (initial) model iteratively modified in our 2D integrated modelling to fit jointly all the geophysical data was constructed based on previous studies with their interpretations. The LAB for the starting model at transect HT-1 was extrapolated from the map of the lithospheric thickness published by Dérerová et al. (2006). The Moho boundary for the starting model was taken from the map published by Bielik et al. (2018). The depth of the boundary between upper and lower crust for the starting model was taken from (Bielik, 1995). The sedimentary layer for the starting model was constructed based on the data published by Kilényi and Šefara (1989), Krejči and Jurová (1997), and Makarenko et al. (2002).

\section{Results}

The starting 2D lithospheric model described above was in the manual iterative process of the $2 \mathrm{D}$ integrated modelling modified to obtain the best possible fit, jointly, for all modelled input geophysical data. The shape and the depth of the structural density interfaces and the modelled lithospheric bodies were modified wherever needed, along with the thermal and density-related parameters. Since the near-surface structures, the sedimentary layers and the upper crust, are quite well known, the more significant 
modifications focused on deeper structures like the Moho and the LAB. The model was modified until we reached a reasonable fit between the given input geophysical data and the model predictions (the same data obtained as the output generated by the subsurface structure). The resultant model is presented in Fig. 2 along with the final set of densities and thermal parameters listed in Table 1.

Table 1. Densities and thermal properties of the different bodies used in our modelling along transect HT-1. No.: reference number in Figure 2, HP: heat production $\left(\mu \mathrm{W} \mathrm{m}^{-3}\right)$, TC: thermal conductivity $\left(\mathrm{W} \mathrm{m}^{-1} \mathrm{~K}^{-1}\right), \rho_{0}$ : density at room temperature $\left(\mathrm{kg} \mathrm{m}^{-3}\right)$.

\begin{tabular}{|c|l|c|c|c|}
\hline No. & Unit & HP & TC & $\boldsymbol{\rho}_{\mathbf{O}}$ \\
\hline 1 & Pannonian Basin sediments & 3.5 & 2.5 & 2500 \\
\hline 2 & Flysch sediments & 1.0 & 2.0 & 2610 \\
\hline 3 & Pannonian upper crust & 3.0 & 2.5 & 2750 \\
\hline 4 & Carpathian/European platform upper crust & 2.0 & 2.5 & 2750 \\
\hline 5 & Lower crust & 0.2 & 2.0 & 2950 \\
\hline 6 & Lower (mantle) lithosphere & 0.05 & 3.4 & 3200 \\
\hline
\end{tabular}

The main focus of our study is the depth and shape of the LAB. In the Pannonian Basin the modelled depth is about $80-90 \mathrm{~km}$ and rapidly increases towards the Western Carpathians, where it reaches values of 145$150 \mathrm{~km}$, and 135-140 km beneath the European platform. We can observe the occurrence of a weakly pronounced lithospheric root under the Western Carpathians. This lithospheric thickening is interpreted as a small remnant of a subducted slab. It has been previously detected by Spakman et al. (1993), Lillie et al. (1994), and Wortel and Spakman (2000). It is also in agreement with our previous models in the Western Carpathians presented by Zeyen et al. (2002) and Dérerová et al. (2006).

The Moho depth varies between 25 and $27.5 \mathrm{~km}$ beneath the Pannonian Basin and about $37-40 \mathrm{~km}$ beneath the Western Carpathians. It reaches about $30-37 \mathrm{~km}$ beneath the European platform. Figure 2 indicates that thickening of the Moho boundary underneath the Western Carpathians follows the thickening of the lithosphere in this area. These values are in correlation with our previous modelling (Zeyen et al., 2002), but differ somewhat from the data taken from the map published by Bielik et al. (2018), which served as input data for our initial model. The main difference was observed 


\section{Profile HT-1}

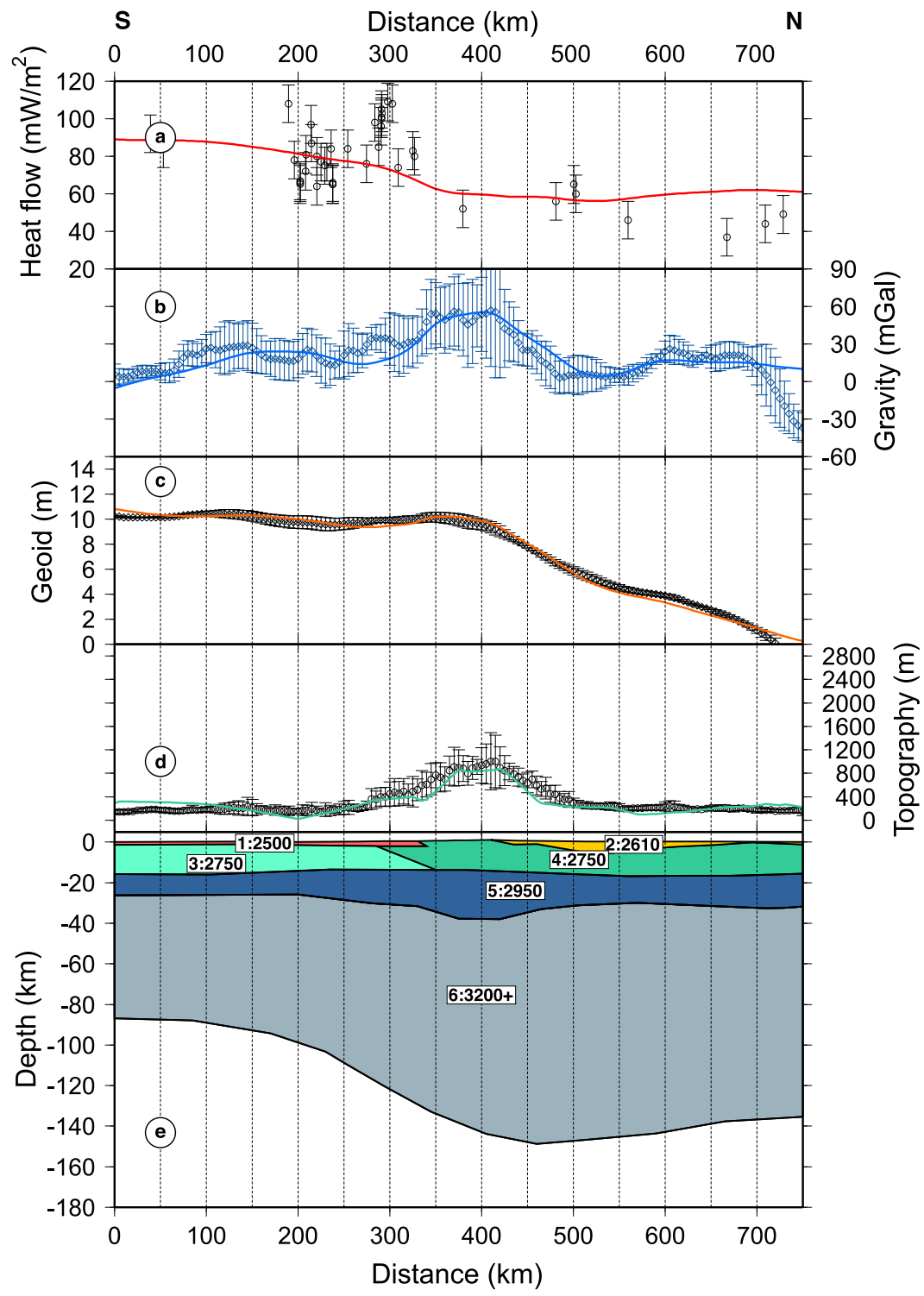

Fig. 2. Lithospheric model along transect HT-1. (a) Surface heat flow, (b) free air gravity anomaly, (c) geoid, (d) topography with dots corresponding to measured data with uncertainty bars and solid lines to calculated values. Numbers in (e) correspond to material number in Table 1. 
along our profile beneath the European platform, where Bielik et al. (2018) suggest values up to $45 \mathrm{~km}$, while we modelled significantly lower values with a maximum around $37 \mathrm{~km}$.

The depth of the boundary between upper and lower crust changed minimally and varies between 17 and $20 \mathrm{~km}$, which is in correlation with data published by Bielik (1995).

In order to fit the surface heat flow data, the upper crust had to be divided into two units that differ in their thermal parameters, while the densities remain the same (Table 1). Although the heat flow data show a high degree of scatter, from Fig. 2 it is obvious that the Pannonian Basin is hotter and with much higher values of surface heat flow. To fit this feature, the thermal parameters for the upper crust had to be modified accordingly.

The sedimentary layer changed minimally, only certain corrections regarding the depth of flysch sediments were made.

\section{Conclusions}

We have used the available geological data to construct the initial model, and the available geophysical data to perform joint 2D integrated modelling that combines surface heat flow data, topographic heights, gravity anomalies and short-wavelength (stripped of degree and order 8 components) geoidal heights data. We focused mainly on the deeper parts of the lithosphere, the Moho boundary and the lithosphere-asthenosphere boundary (LAB). Our final model shows that the lithospheric thickness increases from its minimum 80-90 km beneath the Pannonian Basin up to $145-150 \mathrm{~km}$ in the Western Carpathians, and 135-140 km beneath the European platform. The maximum values and the shape of the LAB beneath the Western Carpathians suggest the formation of a lithospheric root. The lithospheric thickening is accompanied by crustal thickening (Moho) beneath the Western Carpathians.

Acknowledgements. This research was supported by the Slovak Grant Agency VEGA, grants No. 2/0006/19 and 2/0100/20, by the Slovak Research and Development Agency under grants APVV-16-0146 (acronym WECAFARE), APVV-16-0482 (acronym LITHORES) and APVV-19-0150 (acronym ALCABA). It also has been supported by Visegrad Grant CAPABLE No. 21930053. Authors are grateful to Prof. Hermann Zeyen of University de la Terre for permission to use 2D integrated modelling software. 


\section{References}

Bielik M., 1988: A preliminary stripped gravity map of the Pannonian Basin. Phys. Earth Planet. Inter., 51, 1-3, 185-189, doi: 10.1016/0031-9201(88)90043-X.

Bielik M., 1995: Continental convergence in the area of the Western Carpathians on the basis of density modeling. Geol. Carpath., 46, 1, 3-12, ISSN 1335-0552.

Bielik M., Makarenko I., Starostenko V., Legostaeva O., Dérerová J., Šefara J., Pašteka R. 2005: New 3D gravity modeling in the Carpathian-Pannonian region. Contrib. Geophys. Geod., 35, 1, 65-78.

Bielik M., Makarenko I., Csicsay K., Legostaeva O., Starostenko V., Savchenko A., Šimonová B., Dérerová J., Fojtíková L., Pašteka R., Vozár J., 2018: The refined Moho depth map in the Carpathian-Pannonian region. Contrib. Geophys. Geod., 48, 2, 179-190, ISSN 1335-2806, doi: 10.2478/congeo-2018-0007.

Bowin C., 1991: The Earth's gravity field and plate tectonics. Tectonophysics, 187, 1-3, 69-89, doi: 10.1016/0040-1951(91) 90414-N.

Chase C. G., Libarkin J. A., Sussman A. J., 2002: Colorado Plateau: Geoid and Means of Isostatic Support. Int. Geol. Rev., 44, 7, 575-587, doi: 10.2747/0020-6814.44 .7 .575 .

Csontos L., Nagymarosy A., Horváth F., Kováč M., 1992: Tertiary evolution of the IntraCarpathian area: A model. Tectonophysics, 208, 1-3, 221-241, doi: 10.1016/0040 -1951 (92) 90346-8.

Dadlez R., Grad M., Guterch A., 2005: Crustal structure below the Polish Basin: Is it composed of proximal terranes derived from Baltica? Tectonophysics, 411, 1-4, 111-128, doi: $10.1016 /$ j.tecto.2005.09.004.

Dérerová J., Zeyen H., Bielik M., Salman K., 2006: Application of integrated geophysical modeling for determination of the continental lithospheric thermal structure in the Eastern Carpathians. Tectonics, 25, 3, TC3009, doi: 10.1029/2005TC001883.

Gesch D. B., Verdin K. L., Greenlee S. K., 1999: New land surface digital elevation model covers the Earth. Eos, Trans. AGU, 80, 6, 69-70, doi: 10.1029/99E000050.

Haas J. (Ed.), Hámor G., Jámbor Á., Kovács S., Nagymarosy A., Szedekényi T., 2001: Geology of Hungary. Eötvös University Press, Budapest, 317 p.

Hlavňová P., Bielik M., Dérerová J., Kohút I., Pašiaková M., 2015: A new lithospheric model in the eastern part of the Western Carpatians: 2D integrated modelling. Contrib. Geophys. Geod., 45, 1, 13-23, ISSN 1335-2806, doi : 10.1515/congeo-2015 -0010 .

Hók J., Šujan M., Šipka F., 2014: Tectonic division of the Western Carpathians: an overview and a new approach (Tektonické členenie Západných Karpát - prehlad názorov a nový prístup). Acta Geol. Slovaca, 6, 2, 135-143 (in Slovak with English summary).

Horváth F., 1993: Towards a mechanical model for the formation of the Pannonian Basin. Tectonophysics, 226, 1-4, 333-357, doi : 10.1016/0040-1951(93) 90126-5.

Kilényi E., Šefara J. (Eds.), 1989: Pre-Tertiary basement countour map of the Carpathian Basin beneath Austria, Czechoslovakia and Hungary. ELGI, Budapest. 
Kováč M., 2000: Geodynamic, paleogeographic and structural evolution of the Carpathian-Pannonian region during the Miocene: New sight on the Neogene basins of Slovakia (Geodynamický, paleogeografický a štruktúrny vývoj Karpatsko-Panónskeho regiónu v Miocéne: Nový pohlad na Neogénne panvy Slovenska). VEDA, Bratislava, 202 p. (in Slovak).

Krejčí O., Jurová Z., 1997: Structural map of the basement of the Flysch nappe sediments (Strukturní mapa báze sedimentu flyšových příkrovú s vyznačením prognózních ploch). Manuskript Czech Geol. Surv., Brno, Czech Republic (in Czech).

Lachenbruch A. H., Morgan P., 1990: Continental extension, magmatism and elevation; formal relations and rules of thumb. Tectonophysics, 174, 1-2, 39-62, doi : 10.1016/ 0040-1951 (90) 90383-J.

Lillie J. R., Bielik M., Babuška V., Plomerová J., 1994: Gravity modelling of the Lithosphere in the Eastern Alpine-Western Carpathian-Pannonian Basin region. Tectonophysics, 231, 4, 215-235, doi : 10.1016/0040-1951(94)90036-1.

Makarenko I., Legostaeva O., Bielik M., Starostenko V., Dérerová J., Šefara J., 2002: 3D gravity effects o the sedimentary complexes in the Carpathian-Pannonian region. Geol. Carpath., 53, special issue, Proceedings of XVII. Congress of CarpathianBalkan Geological Association, Bratislava, September 1-4, 2002, ISSN 1335-0552.

McCann T. (Ed.), 2008a: The Geology of Central Europe. Volume 1: Precambrian and Palaeozoic. Geological Society, London, 784 p.

McCann T. (Ed.), 2008b: The Geology of Central Europe. Volume 2: Mesozoic and Cenozoic. Geological Society, London, 736 p.

Pavlis N. K., Holmes S. A., Kenyon S. C., Factor J. K., 2008: An Earth gravitational model to degree 2160: EGM2008. EGU General Assembly 2008, Vienna, Austria, April 13-18, 2008.

Pharaoh T. C., 1999: Palaeozoic terranes and their lithospheric boundaries within the Trans-European Suture Zone, TESZ: A review. Tectonophysics, 314, 1-3, 17-41, doi : 10.1016/S0040-1951(99)00235-8.

Plašienka D., Grecula P., Putiš M., Hovorka D., Kováč M., Hovorka D., 1997: Evolution and structure of the Western Carpathians: an overview. In: Grecula P., Hovorka D., Putiš M. (Eds.): Geological evolution of the Western Carpathians. Miner. Slovaca, Monograph, Bratislava, 1-24i.

Plašienka D., Bučová J., Šimonová V., 2020: Variable structural styles and tectonic evolution of an ancient backstop boundary: the Pieniny Klippen Belt of the Western Carpathians. Int. J. Earth Sci., 109, 1355-1376, doi: 10.1007/s00531-019-0178 9-5.

Pollack H. N., Hurter S. J., Johnson J. R., 1993: Heat flow from the Earth's interior: Analysis of the global data set. Rev. Geophys., 31, 3, 267-280, doi: 10.1029/93RG 01249.

Sandwell D. T., Smith W. H. F., 1997: Marine gravity anomalies from Geosat and ERS-1 satellite altimetry. J. Geophys. Res. Atmos., 102, B5, 10039-10054, doi : 10.1029/ 96JB03223. 
Spakman W., Van der Lee S., Van der Hilst R., 1993: Travel-time tomography of the European-Mediterranean mantle down to $1400 \mathrm{~km}$. Phys. Earth Planet. Inter., 79, 1-2, 3-74, doi : 10.1016/0031-9201(93) 90142-V.

Talwani M., Worzel J. L., Landisman M., 1959: Rapid gravity computations for twodimensional bodies with application to the Mendocino submarine fracture zone. J. Geophys. Res., 64, 1, 49-59, doi: 10.1029/JZ064i001p00049.

Vozár J., Bezák V., Elečko M., Gross P., Konečný V., Lexa J., Mello J., Polák M., Potfaj M., Rakús M., Vass D., Vozárová A., 1999: Geological map of Slovak Republic. In: Vozár J., Šantavý J. (Eds.): Atlas of deep reflection seismic profiles of the Western Carpathians and its interpretation. Ministry of Environment of the Slovak Republic, Geological Survey of the Slovak Republic, Geocomplex, Inc., Bratislava, 31.

Wortel M. J. R., Spakman W., 2000: Subduction and slab detachment in the Mediterranean-Carpathian region. Science, 290, 5498, 1910-1917, doi: 10.1126/science. 290.5498.1910.

Zeyen H., Fernàndez M., 1994: Integrated lithospheric modeling combining thermal, gravity and local isostasy analysis: Application to the NE Spanish Geotransect. J. Geophys. Res. Solid Earth, 99, B9, 18089-18102, doi: 10.1029/94JB00898.

Zeyen H., Dérerová J., Bielik M., 2002: Determination of the continental lithosphere thermal structure in the western Carpathians: Integrated modelling of surface heat flow, gravity anomalies and topography. Phys. Earth Planet. Inter., 134, 1-2, 89104, doi : 10.1016/S0031-9201(02)00155-3.

Zeyen H., Ayarza P., Fernàndez M., Rimi A., 2005: Lithospheric structure under the western African-European plate boundary: A transect across the Atlas Mountains and the Gulf of Cadiz. Tectonics, 24, 2, TC2001, doi : 10.1029/2004TC001639. 